\title{
Eksisterer folkebibliotekerne om 10 år?
}

\section{Anmeldelse af Birger Hjørland}

Huymans, Frank \& Hillebrink, Carlien (2008). The future of the Dutch public library: ten years on. The Hague: Netherlands Institute for Social Research. (Engelsk oversattelse af: De openbare bibliotheek tien jaar van nu). ISBN: 9789037703801 . Kan bestilles som bog eller frit downloades fra: http://www. scp.nl/dsresource? objectid $=19797 \&$ type $=$ org

Det nederlandske institut for socialforskning har udført denne undersøgelse af folkebibliotekernes fremtid i Nederlandene. Det er en omfattende empirisk undersøgelse af trends i benyttelsen af folkebibliotekerne, men det er også et fremtidsstudie af, hvordan udviklingen vil blive i perioden 2015-2020. Endelig rummer bogen anbefalinger for, hvad der kan gøres for at fastholde folkebiblioteket som en vigtig institution i samfundet.

Ifølge en citeret kilde, Richtlijn voor basisbibliotheken (2005), opregner folkebibliotekerne fem funktioner, som de selv opfatter som deres basisfunktioner:

- Viden og information

- Udvikling og uddannelse

- Kunst og kultur

- Læsning og litteratur

- Møder og debat

Birger Hjørland er professor ved Danmarks Biblioteksskole,bh@db.dk.
Biblioteker bør i princippet være aktive i alle fem områder, der styrker hinanden og tilsammen udgør en sammenhængende helhed. Folkebiblioteket ses som værende baseret på ni normative principper:

- Adgang, tilgængelighed

- Diversitet, pluralisme

- Uafhængighed, objektivitet

- Solidaritet, social inklusion

- Social kontrol, integration

- Vedligeholdelsen af det symbolske miljø

- Pålidelighed, præcision

- Professionalisme, ekspertise

- Aktualitet, fornyelse.

Folkebiblioteket er den største kulturelle institution i Nederlandene med fire millioner brugere og 130 millioner udlån årligt. Trods dette er bibliotekerne under pres og udlånstallene har været støt faldende gennem adskillige år. Det er især funktionen "Viden og information", der er truet, fordi situationen for de fleste brugere har udviklet sig fra knaphed på information til overflod af information, og fordi informationsteknologien muliggør langt hurtigere, bredere, mere tilgængelige, mere internationale og mere brugertilpassede tilbud, hvorfor folkebibliotekernes samlinger opleves som en begrænset selektion sammenlignet med det totale udbud.

Baseret på en SWOT-analyse (d.v.s. analyse af styrker, svagheder, muligheder og trusler), en fremskrivning af udviklingstrenden og en teoretisk model forudsiger bogen fortsat fald $\mathrm{i}$ benyttelsen og aftagende 
politisk/økonomisk støtte til folkebibliotekerne. I fremtidsanalyse nummer to forudses det at faldet $\mathrm{i}$ benyttelsen af folkebibliotekerne vil accelerere i det kommende årti sammenlignet med det forgangne årti. Faldet vil især finde sted på de aktiviteter, der er en betingelse for varetagelsen af de øvrige funktioner.

Det forhold, at folkebibliotekerne kan imødese faldende økonomisk støtte fra politisk side, ser rapporten imidlertid ikke som en ønskværdig udvikling. Forfatterne mener ikke, at de uønskede konsekvenser primært er konsekvenserne for bibliotekerne selv men for de funktioner, som de understøtter. Baseret på de ni nævnte normative principper analyseres forhold, som markedskræfterne ikke menes at kunne opfylde, hvis det ene eller det andet af de to fremtidsscenarier går i opfyldelse.

Markedsøkonomien menes ikke på samme måde som de offentligt støttede folkebiblioteker at kunne sikre uafhængighed, diversitet, objektivitet, pålidelighed og social inklusion, hvorfor en konklusion kan være, at der stadig vil være sund fornuft $i$ at støtte folkebibliotekerne om 10 år, for at de kan virke som en offentligt finansieret korrektion af markedskræfterne. Dette er imidlertid betinget af, at de opfattes som den bedste partner af de offentlige myndigheder til at udfylde de identificerede mangler, hvilket ikke er en given ting.

Det afsluttende kapitel 8 rummer forslag til ændringer i folkebibliotekernes og de relevante myndigheders "policy", herunder at gøre materialerne lettere at finde, at øge brugernes informationskompetence, at forbedre såvel front-office som back-office funktioner m.v. Jeg vil overlade det til læserens selv at læse resten af anbefalingerne og forholde sig til forslagene.

For anmelderens egen regning kun denne tilføjelse: Visioner om fremtiden tager efter min opfattelse alt for ofte udgangspunkt i folkebiblioteket som et fysisk rum på bekostning af udviklingen af relevante digitale tjenester. Ikke at det fysiske rum skal undervurderes, men vi kan ikke hænge alt op på den forudsætning. Én af mine kolleger (Rune Eriksson) har meget klare bud på, hvordan folkebibliotekerne kan øge klassifikation og indeksering af skønlitteratur. Det er efter min opfattelse ét eksempel på påtrængende udviklingsbehov i folkebibliotekssektoren, der ikke er betinget af fysiske biblioteker, men kan leveres som en digital service.

Min norske kollega Ragnar Audunson har især forsket i folkebibliotekernes fremtid ud fra et perspektiv om lav-intensive væresteder. Dette er uden tvivl også en vigtig funktion at have for øje. Men det er jo ret uambitiøst sammenlignet med visioner om folkebiblioteket som en fortsat hovedhjørnesten i videnssamfundet. Som beskrevet i et stillingsopslag ${ }^{1}$ i 2008 : "Danmarks Biblioteksforening søger en direktør med hjerte for biblioteksarbejdet og med de professionelle kompetencer, der skal til for at skabe resultater med hensyn til [punkt 1]: at fastholde og forstærke folkebibliotekernes status som et uerstatteligt element i Danmarks styrkeposition i en globaliseret verden". Dét er ambitiøst!

Blandt begrænsningerne i bogen under anmeldelse vil jeg nævne at den er ret ukonkret med hensyn til svagheder i de nuværende muligheder for at søge og organisere information, og den forholder sig slet ikke til BDI som forskningsfag, herunder mulighederne for at levere information direkte til brugernes PC. Visioner er vigtige, og det er vigtigt at biblioteksskolens forskning bygger på visioner og er en integreret del i udviklingen af den samlede bibliotekssektor ${ }^{2}$. Forskning er et afgørende element, hvis den vel at mærke er visionær.

\section{Konklusion}

$\mathrm{Vi}$, der forsker og underviser i BDI, er forpligtet til at have visioner om, hvad det er, vi kan bidrage til, dvs. visioner om bibliotekers og informationstjenesters fremtid. Der er i dag en mangel på kvalificerede bud, som vi kan forholde os til, diskutere og videreudvikle. Denne bog er så absolut en væsentlig analyse af den nuværende situation og de udfordringer folkebibliotekerne står overfor. Selvom bogen vedrører et andet land, er problemerne i Danmark grundlæggende de samme.

\section{Noter}

1. http://www.dbf.dk/Default.aspx?ID=5347

2. På netstedet www.db.dk/bh/Core $\% 20$ Concepts $\% 20$ in $\% 20$ LIS/articles\%20a-z/forecasts_in_information_science.htm har jeg samlet nogle citater og litteraturhenvisninger om BDI-sektorens fremtid. 